
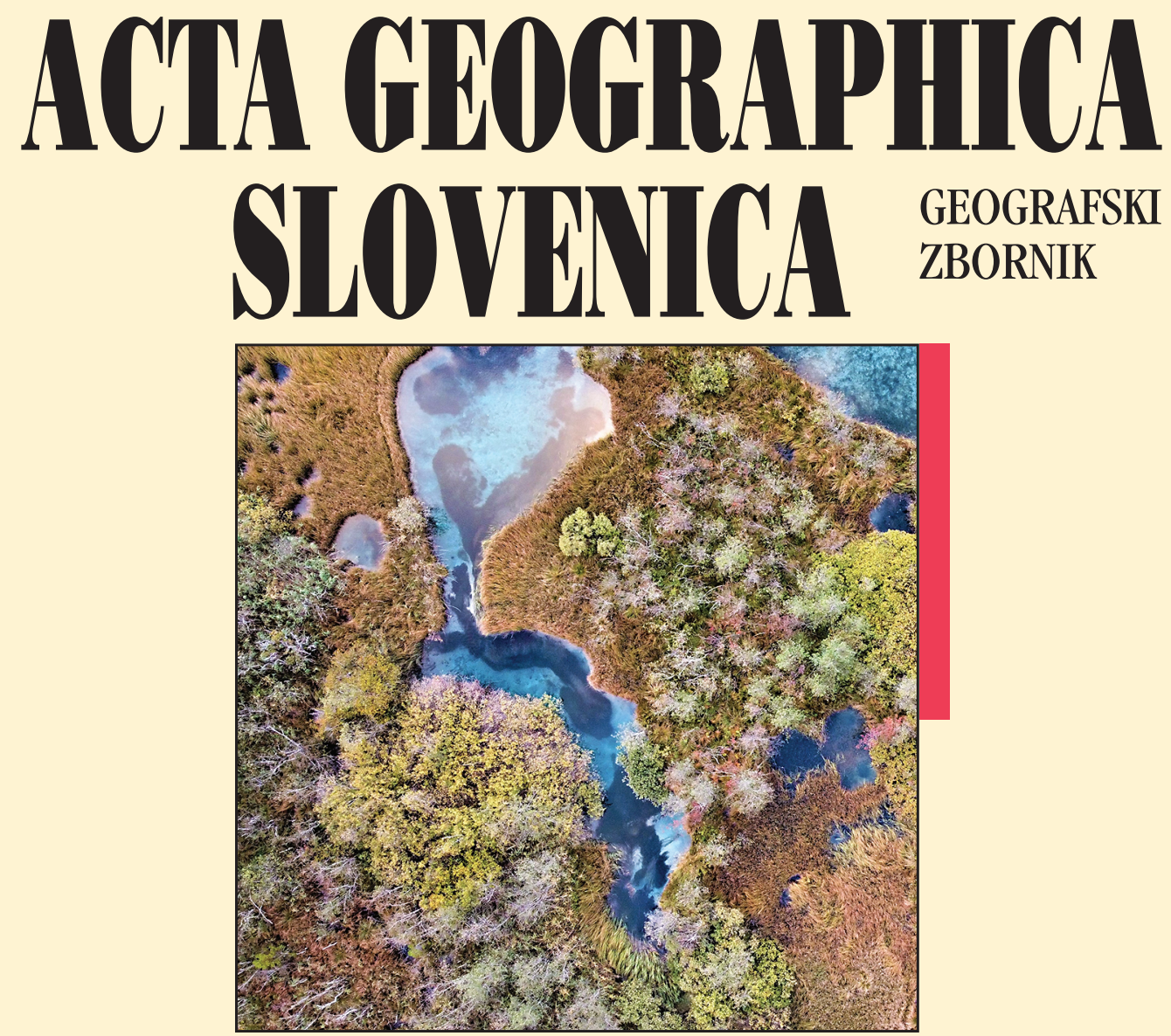


\section{ACTA GEOGRAPHICA SLOVENICA GEOGRAFSKI ZBORNIK 61-2 • 2021}

\section{Contents}

Đorđije VASILJEVIĆ, Milica BEGAN, Miroslav VUJIČIĆ, Thomas HOSE, Uglješa STANKOV

Does geosite interpretation lead to conservation? A case study of the Sićevo Gorge (Serbia)

Gabrijela POPOVIĆ, Dragiša STANUJKIĆ, Predrag MIMOVIĆ, Goran MILOVANOVIĆ, Darjan KARABAŠEVIĆ, Pavle BRZAKOVIĆ, Aleksandar BRZAKOVIĆ

An integrated SWOT - extended PIPRECIA model for identifying key determinants of tourism development: The case of Serbia

Robert KALBARCZYK, Eliza KALBARCZYK

Precipitation variability, trends and regions in Poland: Temporal and spatial distribution in the years 1951-2018

Ivana CRLJENKO, Matjaž GERŠIČ

A comparison of the beginnings of exonym standardization in Croatian and Slovenian

Tadej BREZINA, Jernej TIRAN, Matej OGRIN, Barbara LAA

COVID-19 impact on daily mobility in Slovenia

Maruša GOLUŽA, Maruška ŠUBIC-KOVAČ, Drago KOS, David BOLE

How the state legitimizes national development projects: The Third Development Axis case study, Slovenia

Tin LUKIĆ, Tanja MICIĆ PONJIGER, Biljana BASARIN, Dušan SAKULSKI, Milivoj GAVRILOV, Slobodan MARKOVIĆ, Matija ZORN, Blaž KOMAC, Miško MILANOVIĆ, Dragoslav PAVIĆ, Minučer MESAROŠ, Nemanja MARKOVIĆ, Uroš DURLEVIĆ, Cezar MORAR, Aleksandar PETROVIĆ Application of Angot precipitation index in the assessment of rainfall erosivity: Vojvodina Region case study (North Serbia)

Janij OBLAK, Mira KOBOLD, Mojca ŠRAJ

The influence of climate change on discharge fluctuations in Slovenian rivers

Vladimir STOJANOVIĆ, Dubravka MILIĆ, Sanja OBRADOVIĆ, Jovana VANOVAC, Dimitrije RADIŠIĆ

The role of ecotourism in community development: The case of the Zasavica Special Nature Reserve, Serbia

Marko V. MILOŠEVIĆ, Dragoljub ŠTRBAC, Jelena ĆALIĆ, Milan RADOVANOVIĆ Detection of earthflow dynamics using medium-resolution digital terrain models: Diachronic perspective of the Jovac earthflow, Southern Serbia

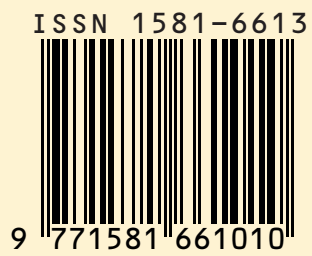




\section{DETECTION OF EARTHFLOW DYNAMICS USING MEDIUM-RESOLUTION DIGITAL TERRAIN MODELS: DIACHRONIC PERSPECTIVE OF THE JOVAC EARTHFLOW, SOUTHERN SERBIA}

Marko V. Milošević, Dragoljub Štrbac, Jelena Ćalić, Milan Radovanović

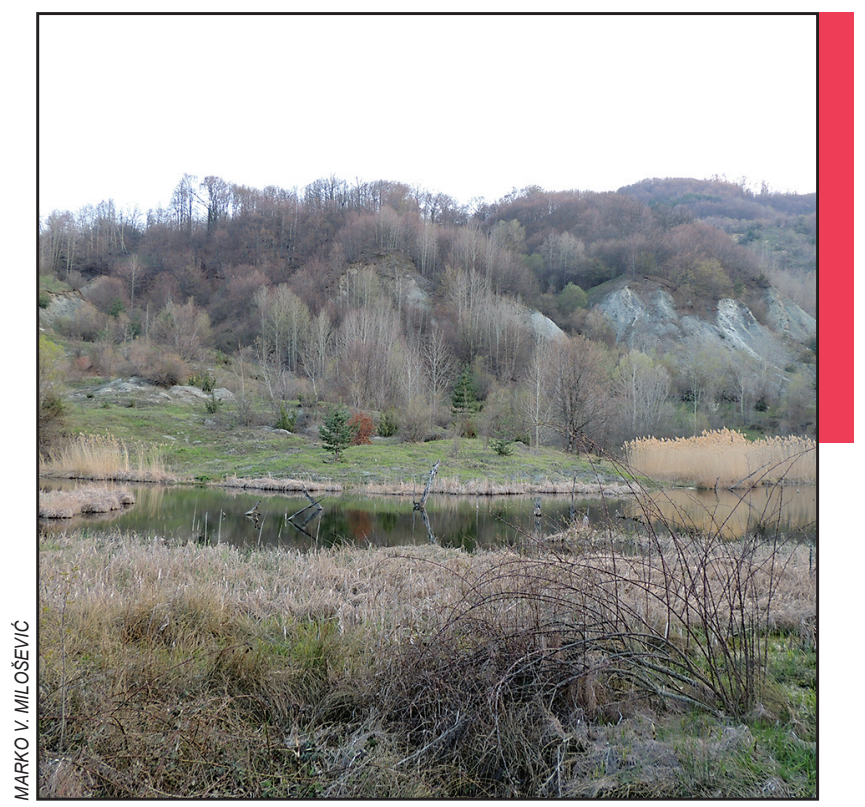

Jovac earthflow, head scarp zone. 
DOI: https://doi.org/10.3986/AGS.9818

UDC: $911.2: 551.435 .62(497.11-13)$

COBISS: 1.01

Marko V. Milošević ${ }^{1}$, Dragoljub Štrbac ${ }^{1}$, Jelena Ćalićl ${ }^{1}$ Milan Radovanovićc ${ }^{1,2}$

\title{
Detection of earthflow dynamics using medium-resolution digital terrain models: Diachronic perspective of the Jovac earthflow, Southern Serbia
}

\begin{abstract}
The paper presents and discusses the landslide research procedure related to the topography before and after its occurrence, using the comparative analysis of two medium-resolution digital terrain models. The case study is the Jovac mega-landslide - the largest landslide to occur in Serbia in the last 100 years, active for three days in February 1977. The indicators used to determine the volume and movement mechanism were the spatial distribution of elevation differences within the two digital terrain models (DTM), and the analysis of geomorphological features before the landslide. The obtained elevation differences allowed the definition of the approximate landslide volume: $11.6 \times 10^{6} \mathrm{~m}^{3}$. All the data obtained indicate that the movement mechanism falls into the category of earthflow.
\end{abstract}

KEY WORDS: landslide, earthflow, GIS analysis, Jovac, Serbia

\section{Zaznavanje dinamike premikanja zemeljskih gmot $\mathrm{z}$ uporabo digitalnih modelov višin srednje ločljivosti: Diakronična perspektiva plazu Jovac, južna Srbija}

POVZETEK: Prispevek predstavlja in obravnava postopek raziskovanja zemeljskih plazov, ki se nanaša na topografijo pred nastankom procesa in po njem, s primerjalno analizo dveh digitalnih modelov terena srednje ločljivosti. Študija primera je mega zemeljski plaz Jovac, ki je največji plaz v Srbiji zgodil v zadnjem stoletju in je bil aktiven tri dni februarja 1977. Kazalniki, ki določajo prostornino in mehanizem gibanja, so prostorska porazdelitev višinskih razlik v obeh digitalni modeli terena (DTM), pa tudi analiza predhodnih geomorfoloških značilnosti. Dobljene višinske razlike so omogočile določitev približne prostornine plazu: $11,6 \times 10^{6} \mathrm{~m}^{3}$. Vsi pridobljeni podatki kažejo, da mehanizem gibanja spada v kategorijo zemljinskih tokov.

KLJUČNE BESEDE: zemeljski plaz, drobirski tok, analiza DMR, Jovac, Srbija

The article was submitted for publication on March $22^{\text {nd }}, 2021$.

Uredništvo je prejelo prispevek 22. marca 2021.

\footnotetext{
${ }^{1}$ Serbian Academy of Sciences and Arts, Geographical Institute Jovan Cvijić, Belgrade, Serbia m.milosevic@gi.sanu.ac.rs (https://orcid.org/ 0000-0001-5188-7260), d.strbac@gi.sanu.ac.rs (https://orcid.org/ 0000-0001-9946-7978), j.calic@gi.sanu.ac.rs (https://orcid.org/ 0000-0002-7271-5561), m.radovanovic@gi.sanu.ac.rs (https://orcid.org/0000-0002-9702-3879)

${ }^{2}$ South Ural State University, Institute of Sports, Tourism and Service, Chelyabinsk, Russia m.radovanovic@gi.sanu.ac.rs (https://orcid.org/0000-0002-9702-3879)
} 


\section{Introduction}

The article deals with earthflow as a specific form/process of landslides from the perspective of changing topography, within a case study of the Jovac earthflow in south-eastern Serbia. Landslides, as one of the most dynamic processes, have been thoroughly studied in the last decades, especially with the rapid development of geomorphometric tools. Among the most cited and important references are the works of Varnes $(1978 ; 1984)$ on landslide hazard zonation, Cruden (1991), Cruden and Varnes (1996) on landslide types, and Hungr, Leroueil and Picarelli (2014) on landslide typification. Cruden's (1991) definition is accepted by the institutions which defined the international standards in landslide research, such as The international geotechnical societies' UNESCO working party for world landslide Inventory (1993), and the International Association for Engineering Geology and the Environment (IAEG) (UNESCO working ... 1993). Furthermore, the above-mentioned references indicate a high degree of diversification of landslides depending on the type of movement and the type of material. Within this typology, the combination of relatively high water content within the small-grained material indicates the landslide category of earthflow, as a subgroup in the landslide classification system. Hungr, Leroueil and Picarelli (2014) define earthflow material as a cohesive, plastic, clayey soil material, often mixed and remoulded with the Liquidity Index below 0.5 . Keefer and Johnson (1983) state that many earthflows contain fragments of material in various stages of remoulding and may carry granular clasts. The IGS Multilingual Landslide Glossary (1993) recognizes the term »flow « (not earthflow) and explains that the distribution of velocities in the displacing mass is similar to that in a viscous fluid. Valuable theoretical background for earthflows is provided by Urciuoli et al. (2016), who explain the relationship between morphological aspects, kinematic behaviour and slope stability conditions.

Digital terrain models (DTMs) are a resource of high importance within landslide detection and research. (Mahalingam and Olsen 2016). Jaboyedoff et al. (2012) see the role of DTM in:

- mass movement detection and characterization,

- hazard assessment and susceptibility mapping,

- modelling, and

- monitoring.

The resolution of a DTM is one of the crucial properties affecting the quality of research results (Lee et al. 2004; Hrvatin and Perko 2005; Santini et al. 2009). In the early period of DTM development, it was assumed that higher resolution would automatically lead to better results (Dietrich and Montgomery 1998). However, recent studies show that resolutions of $2 \mathrm{~m}, 5 \mathrm{~m}$ and $10 \mathrm{~m}$ do not necessarily provide more accurate results (Mahalingam and Olsen 2016; Chen et al. 2020). In some cases with quite high resolution, the DTM may also contain irrelevant data (Tarolli and Tarboton 2006). These can blur the key influencing factors related to sliding during further processing. Examples of this are microtopographic details created by subsequent denudation of the landslide body or small-scale rockfalls in the scarp zone. Therefore, the selection of the optimal DTM resolution must consider the dimensions of the landslide, as well as the context of the analysis (McKean and Roering 2004; Claessens et al. 2005).

Landslide detection using DTM was one of the main aims of our research which was conducted in several time frames. A time frame refers to a state of the topographic surface at the time of the analysis. Performing two or more analyses (assuming that the intervening period included an observable change) provided the insight into the temporal dynamics of the process (Table 1).

Table 1: Landslide detection methods using a Digital Terrain Models (DTM).

\begin{tabular}{|c|c|c|c|}
\hline \multirow{3}{*}{ DTM } & Time frame & Detection method & Detected features \\
\hline & One time frame & $\begin{array}{l}\text { Visual interpretation of DTM } \\
\text { Automated interpretation of DTM }\end{array}$ & $\begin{array}{l}\text { Landslide outlines and morphometric features of the landslide } \\
\text { topographic surface }\end{array}$ \\
\hline & More time frames & $\begin{array}{l}\text { Detection of elevation differences } \\
\text { before and after the landslide } \\
\text { (two DTMs) }\end{array}$ & $\begin{array}{l}\text { Landslide outlines, dimensions, morphometric features of the } \\
\text { landslide topographic surface, depletion zone, accumulation } \\
\text { zone, movement mechanism, monitoring }\end{array}$ \\
\hline
\end{tabular}


Marko V. Milošević, Dragoljub Štrbac, Jelena Ćalić, Milan Radovanović, Detection of earthflow dynamics using ...

Within a time frame, the detection process can be done by two methods: visual interpretation and/or automated recognition. In our case, the visual method combined with fieldwork was the starting point for determining landslide outline (Ardizzone et al. 2007; Amundsen et al. 2010; Guzzetti et al. 2012). Visual interpretation of DTMs relies on hillshade, the generated contours, and the slope of the topographic surface (Van Den Eeckhaut et al. 2007; Schulz 2007; Đomlija 2018). This method of landslide determination is very subjective. In contrast, an objective landslide identification method is based on statistical analyses of DTM-generated morphometric parameters (curvature, surface roughness), which can be used to automatically determine landslide contours (Tarolli, Sofia and Dalla Fontana 2012).

Two or more time-frames recorded within the DTMs allow the application of quantitative methods in defining the outline (boundaries), approximate volume estimation, identification of depletion and accumulation zones, and monitoring of landslide dynamics. The spatial distribution of colluvium can indicate the mechanism of movement (Corsini et al. 2009; Fernández et al. 2011; 2017; Giordan et al. 2013). The work of Conoscenti et al. (2015) is an example of the use of multiple time-frames in DTM analyses. A potential drawback of DTM as a method of landslide detection in general is that the DTM resolution in the analysis phase is usually limited by the pre-sliding input data. In our case, lower data resolution can be expected because the topographic data acquisition took place about 10 years before the landslide event, when mapping methods were not sophisticated as today.

The aim of this article is to determine whether a medium-resolution DTM (sensu, Gigović 2010; Table 2) can be a reliable data source for landslide studies, given the current era of LiDAR dominance. Our hypothesis is that a medium-resolution DTM can prove to be sensitive enough to determine landslide outlines, areas and volumes, as well as reconstruct their movement mechanisms. In this study, two DTMs of the same area are analysed - one is before and one after a landslide, created by applying two different methods. The article describes the details of the superposition procedure applied in order to avoid the systematic errors in determining the elevation differences. In the subsequent analysis, it is possible to define the movement mechanism based on the comparison of the paleo-topography and the present topography of the Jovac landslide.

Table 2: DTM resolutions (after Gigović 2010).

\begin{tabular}{lcc}
\hline Resolution & \multicolumn{2}{c}{ Horizontal distance of elevation points } \\
\cline { 2 - 3 } & In meters & In arc seconds \\
\hline Low & $900-90$ & $30-3$ \\
Medium & $90-30$ & $30-1$ \\
High & $30-10$ & $1-0.3$ \\
Very high & $10-1$ & $0.3-0.03$ \\
\hline
\end{tabular}

\section{Study area and basic geological setting}

The Jovac landslide is located in the villages of Jovac and Ostrovica (Vladičin Han municipality) in southeastern Serbia $\left(\mathrm{N} 44.64^{\circ}, \mathrm{E} 22.003^{\circ}\right)$. The mountainous area within the altitude range $400-800 \mathrm{~m}$ hosts the catchment area of the Jovačka Reka River, the left tributary of the Južna Morava River (Figure 1). The current average precipitation average is about $740 \mathrm{~mm}$, with the peaks in June and May.

Geologically, the study area is located on the southwestern edge of the Eurasian Plate. According to Prelevic et al. (2005), the closure of the Neotethys basin and the collision of the Eurasian Plate with the African Plate triggered large-scale volcanism in early Cenozoic (Cvetković, Šarić and Mladenović 2019). One of the eruption points was located in the zone of the Grot and Oblik peaks (Vukanović et al. 1970), $7 \mathrm{~km}$ west of the present landslide (Figure 1). Pyroclastic material was deposited in the area within the dacite lava eruption. During the Miocene, the lower parts of the drainage area were part of a lacustrine basin where terrigenous sediments were deposited (Vukanović et al. 1970; Babović et al. 1977; Jovanović and Novković 1988). The combination of these lithological components created a landslide-prone setting in the area. Landslide activation occurred in February 1977 and destroyed 70 households in the villages of Jovac and Ostrovica (Petrović and Stanković 1981). 


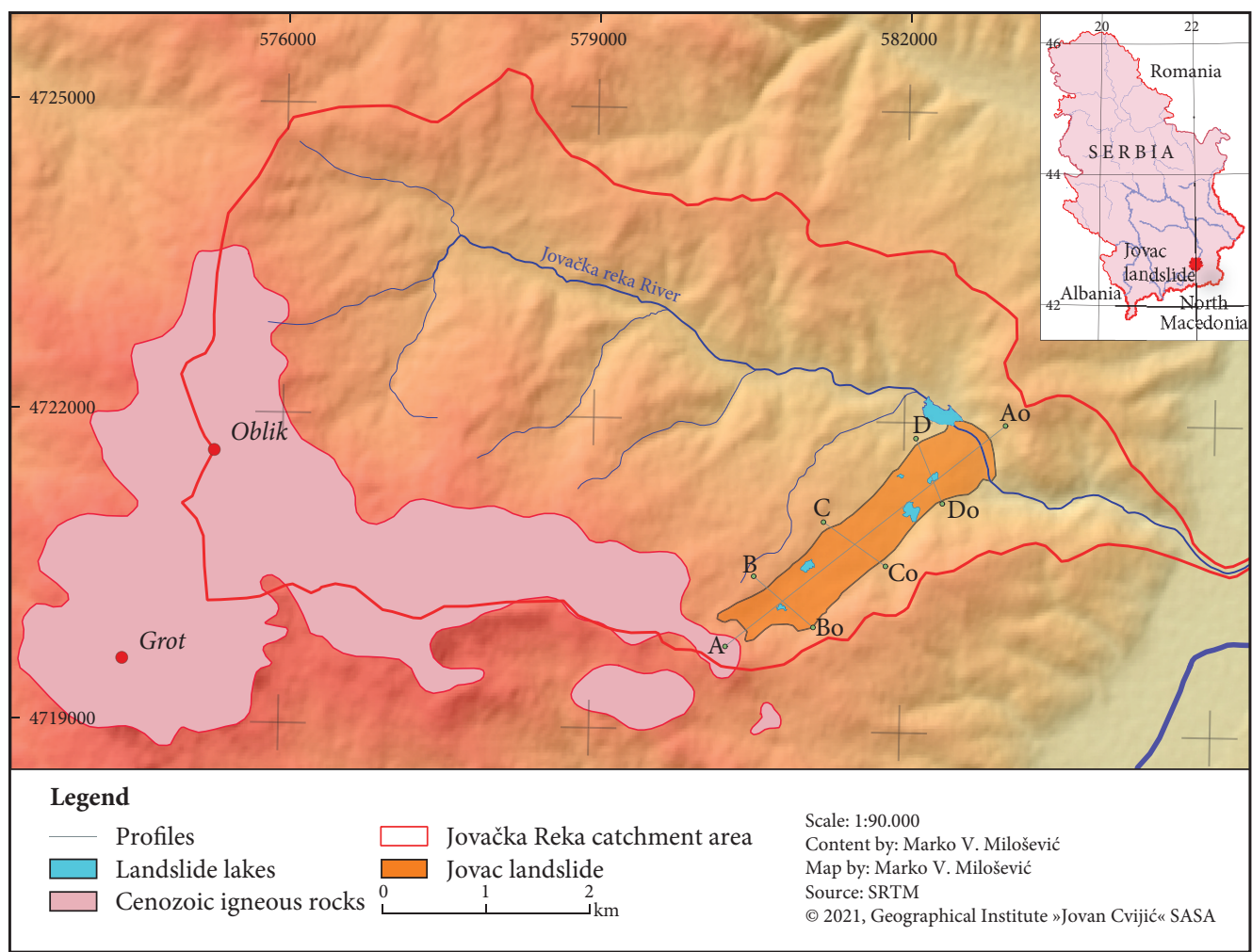

Figure 1: Situation map of the study area (profiles refer to figures 10 and 11).

\subsection{Previous research}

Two papers have already been published on the genesis and morphometry of this landslide (Lazarević 1977; Petrović and Stanković 1981), giving dimensions of $3 \mathrm{~km}^{2}$ area, $50 \mathrm{~m}$ average width and $150 \times 10^{6} \mathrm{~m}^{3}$ volume. Both described the movement mechanism as a typical landslide, using the visual observation and field mapping. Review papers mentioning the Jovac landslide mostly refer to the primary references mentioned (Jevremović, Sunarić and Kostić 2011; Pavlović et al. 2012). Lazarević (1977) defined the Jovac landslide as translational and determined its area to be $1.52 \mathrm{~km}^{2}$. Interestingly he found that there was no synchronized movement of the entire landslide body, but rather that the upper part moved first, while the middle and lower parts moved subsequently. Petrović and Stanković (1981) estimate the average depth of $50 \mathrm{~m}$ and the volume of $150 \times 10^{6} \mathrm{~m}^{3}$. They do not explicitly mention the mechanism of movement but their figure shows a translational landslide character (see Figure 11A).

\section{Data sources and methods}

The aim of the research was to determine the precise outline (boundaries), area, volume and movement type of the Jovac landslide by analysing the topographic data from both, the pre-activation period and the resulting landform after the landslide process was complete. The most accurate data source available for the period before the landslide are the classical topographical maps at $1: 25,000$ published in 1971 . The contour lines of the $1: 25 \mathrm{~K}$ maps were digitized in detail (contour interval $10 \mathrm{~m}$, additional $5 \mathrm{~m}$ and $2.5 \mathrm{~m}$ ) to subsequently create a $30 \times 30 \mathrm{~m}$ DTM referring to the year 1971, in UTM $34 \mathrm{~N}$. The accuracy of the obtained DTM based on digital contour lines from the cartographic records is $2.2 \mathrm{~m}$ for TIN interpolation method 
(Govedarica and Borisov 2011). According to the 1971 map, forest vegetation covered only $12 \%$ of the studied area (in total), in 13 separate fragments; therefore, we do not consider that it affected the accuracy of the data obtained by the photogrammetric method.

For the post-slide period, we used an SRTM DTM $30 \times 30 \mathrm{~m}$ raster referring to the year 2000 . To allow the comparison between the two datasets, the final resolution of $30 \times 30 \mathrm{~m}$ raster cell (pixel) resolution was accepted for the analysis

\subsection{Calculation and analysis of elevation differences}

Raster arithmetic was used to calculate the elevation differences. In the first overlap of two DTMs, the 1971 elevations were subtracted from the 2000 elevations. The analysis of the elevation differences allowed the

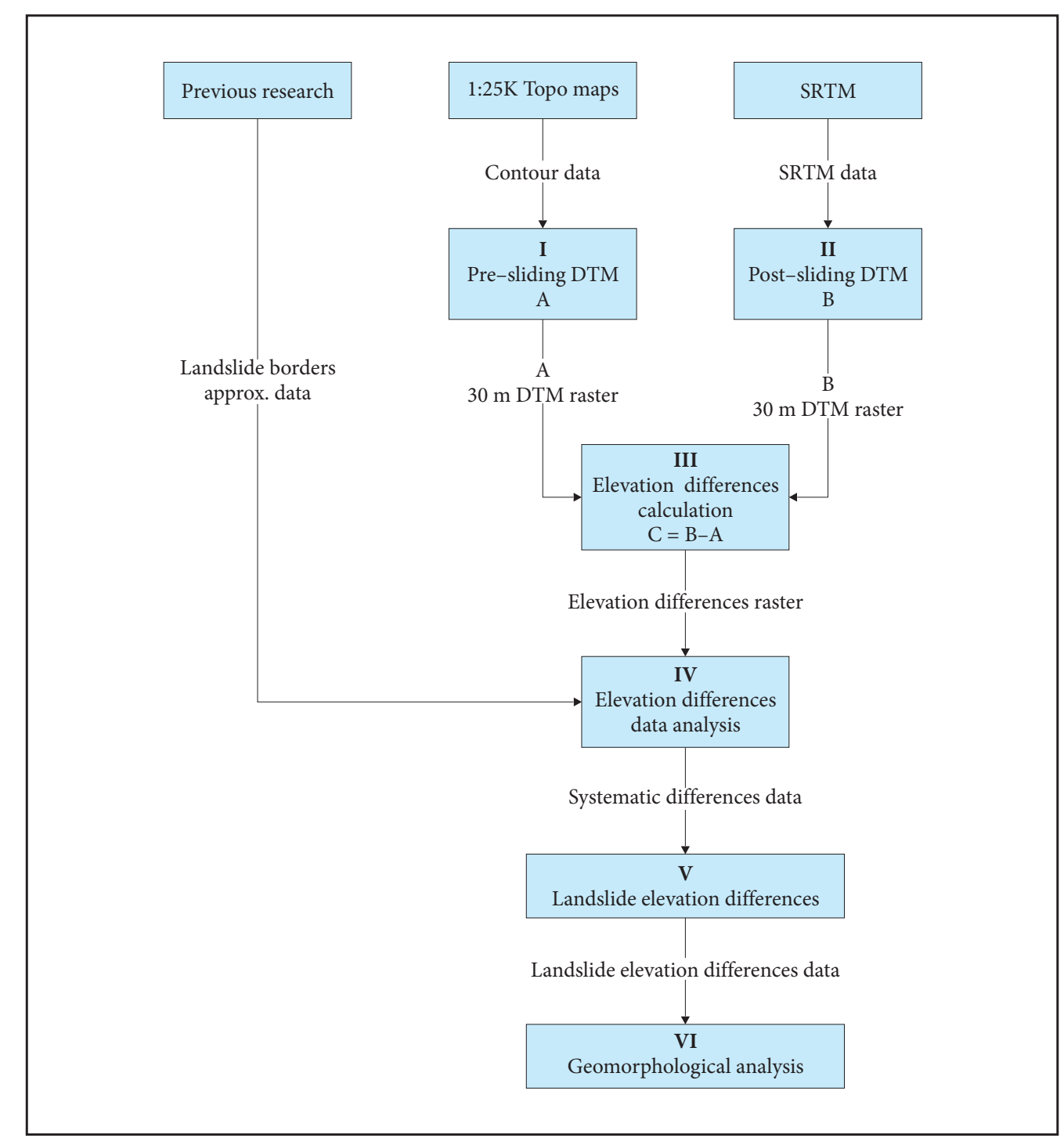


distinction between the sliding and non-sliding (stable) parts of the studied area, which led to the determination of the exact boundary of the landslide.

The non-sliding area was subjected only to statistical analysis of elevation differences, while the sliding area was subjected to geomorphological analysis. The preliminary delineation between these two units was based on cartographic sources, literature, and fieldwork. The size ratio between the units is approximately $1: 3$ (sliding area 1770 pixels; non-sliding area 4878 pixels). The objective of the statistical analysis of the elevation differences of the non-sliding area was to determine the quality of the overlap of two DTMs used, while the task of the geomorphological analysis was to determine the characteristics and consequences of the sliding process.

\subsection{Test of the overlap quality of DTMs}

It is assumed that the non-sliding area was not subject to any influences that would significantly change its elevation. Consequently, the comparison of pre- and post- elevation values should be possible. The characteristics and spatial distribution of the differences would indicate whether there are systematic errors in the overlap of two DTMs obtained using the different data sources.

The total number of pixels (in the non-sliding area) for which the elevation differences were analysed is 4878 , i.e. $146,340 \mathrm{~m}^{2}$. The distribution of the obtained elevation differences is shown in Figure 3.

The arithmetic mean of the elevation differences between the two DTMs is $\overline{\mathrm{x}}=3.940 \mathrm{~m}$, while the standard deviation is $\sigma=4.331 \mathrm{~m}$. The standard deviation is a measure of the quality of the overlap (i.e. agreement of the data).

Two tests of overlap of two DTMs were performed in the following way: One of the models was shifted by one pixel $(30 \mathrm{~m})$ with respect to the other model. The displacement had four directions $-\mathrm{N}, \mathrm{E}, \mathrm{S}$, $\mathrm{W}$. The data on the mean $(\overline{\mathrm{x}})$ and standard deviation $(\sigma)$ of the elevation differences for each movement are given in Table 3. Comparison of the standard deviation values of vertical differences shows that the deviation for the initial model is the smallest, which means that the overlap was correct.

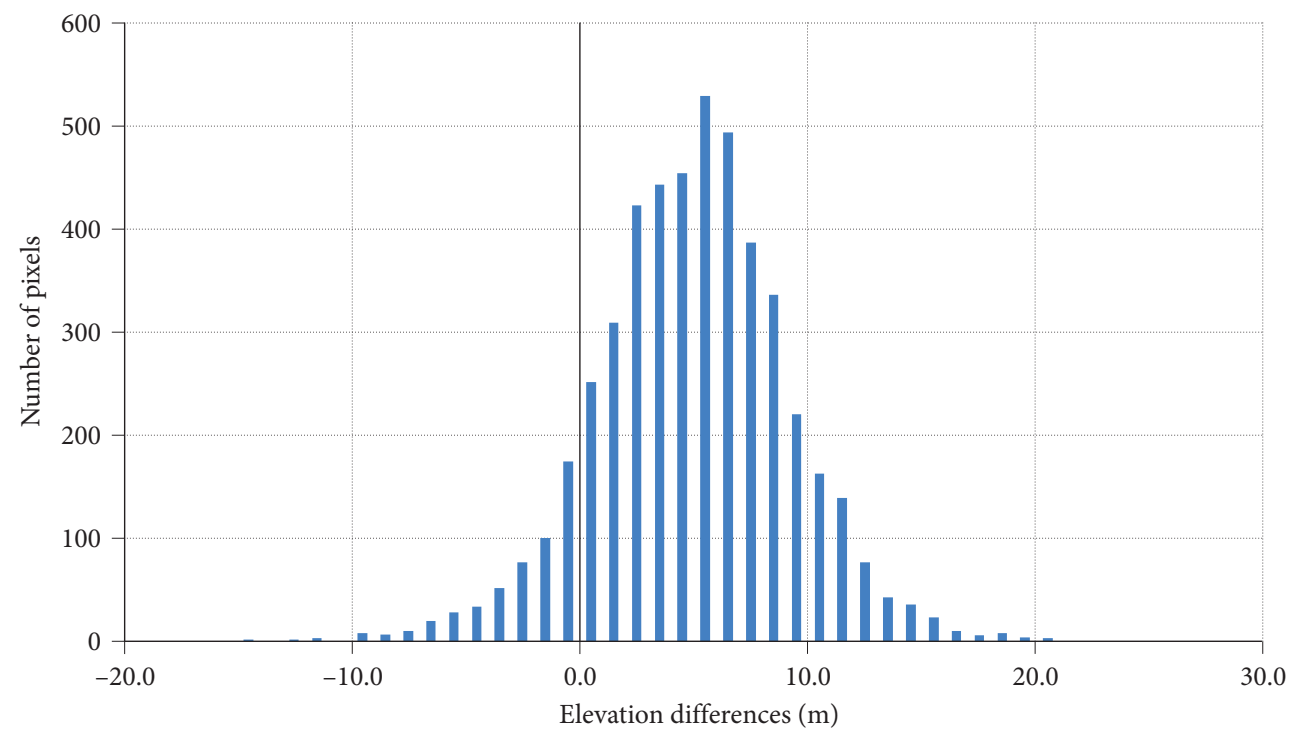

Figure 3: Distribution of elevation differences for the non-sliding (stable) area. 
Marko V. Milošević, Dragoljub Štrbac, Jelena Ćalić, Milan Radovanović, Detection of earthflow dynamics using ...

Table 3: Arithmetic means and standard deviations of the elevation differences during the overlap test.

\begin{tabular}{lrr}
\hline Pixel movement direction & $\bar{x}$ & $\sigma$ \\
\hline North & 8.356 & 5.734 \\
East & 0.748 & 5.082 \\
South & -0.490 & 6.454 \\
West & 7.091 & 6.567 \\
Initial value & 3.940 & 4.331 \\
\hline
\end{tabular}

Definite values of elevation differences were obtained by subtracting the value of $4 \mathrm{~m}$ in the post-sliding DTM in relation to the pre-sliding DTM. As mentioned above, the value of $4 \mathrm{~m}(\overline{\mathrm{x}}=3.940)$ was taken as the value of the systematic error.

\section{Results}

\subsection{Paleotopography}

Analysis of the pre-slide topographic surface (1971 topographic map) revealed colluvial (slope) and fluvial morphogenetic relief types, determined by lithological composition. The indicator for the recognition of colluvial forms are the contour distances which at some places do not regularly follow the contour intervals. Rogers and Chung (2016) suggest that the heterogeneous contour intervals on narrow and elongate surfaces may indicate earthflows. In the case of Jovac, the colluvial traces were present only in the zone of volcanoclastic sediments, mainly in the middle and upper part of the slope (Figure 4). Lazarević (1977) pointed out the signs of former sliding by noting that the pond at the Jezero locality (meaning »lake« in Serbian language) is located in a depression formed during an earlier sliding phase.

This former hydrological feature with a size of $2345 \mathrm{~m}^{2}(45 \times 50 \mathrm{~m}$ in SW-NE direction), is visible on the 1971 topographic map. Our field research results show that there was another pond in the hamlet Deda Dorinci, called Cekino Jezero or Cekina Bara (pond / swamp). Petrović and Stanković (1981) indirectly confirm this by listing the morphological elements of the slope that were present before the activation of the Jovac landslide. They note that the »middle part of the present landslide was subject to dynamic changes, inversely inclined, with microdepressions, rounded hillocks and steep sides, « - features typical for landslides. In the central part of the slope there were hillocks of up to $10 \mathrm{~m}$ relative height, depressions and landslide terraces of different heights.

Fluvial landforms were present only in the catchment area of Manastirski Potok, which extended from the mouth to the Jovačka River (at $400 \mathrm{~km}^{2}$. The lower course of the Manastirski Potok, carved a $40 \mathrm{~m}$ deep gorge in pyroclastics. The valleys of the upstream tributaries are carved in volcanoclastic material with morphological traces of sliding processes.

The longitudinal profile of a stream is one of the indicators of its morphological stage of development. In the case of Manastirski Potok, the profile is not parabolic (as it would be in a balanced state), but uniformly sloping (Figure 5), indicating an early morphogenetic phase and a possible imprinting by a paleo-(colluvial)-relief. The lateral tributary valleys were relatively shallow, with maximum depths up to $10 \mathrm{~m}$, with inherited colluvial landforms - hillocks, depressions, sliding terraces. The hydrographic network consisted only of occasional streams, with a total length of $2910 \mathrm{~m}$.

\subsection{Predispositions for the development of landslides}

There were three main predispositions for the landslide process on the right valley side of the Jovačka Reka River:

- lithological composition,

- morpho-hydrographic conditions: a) surface runoff areas and b) endorheic areas, and

- human impact. 


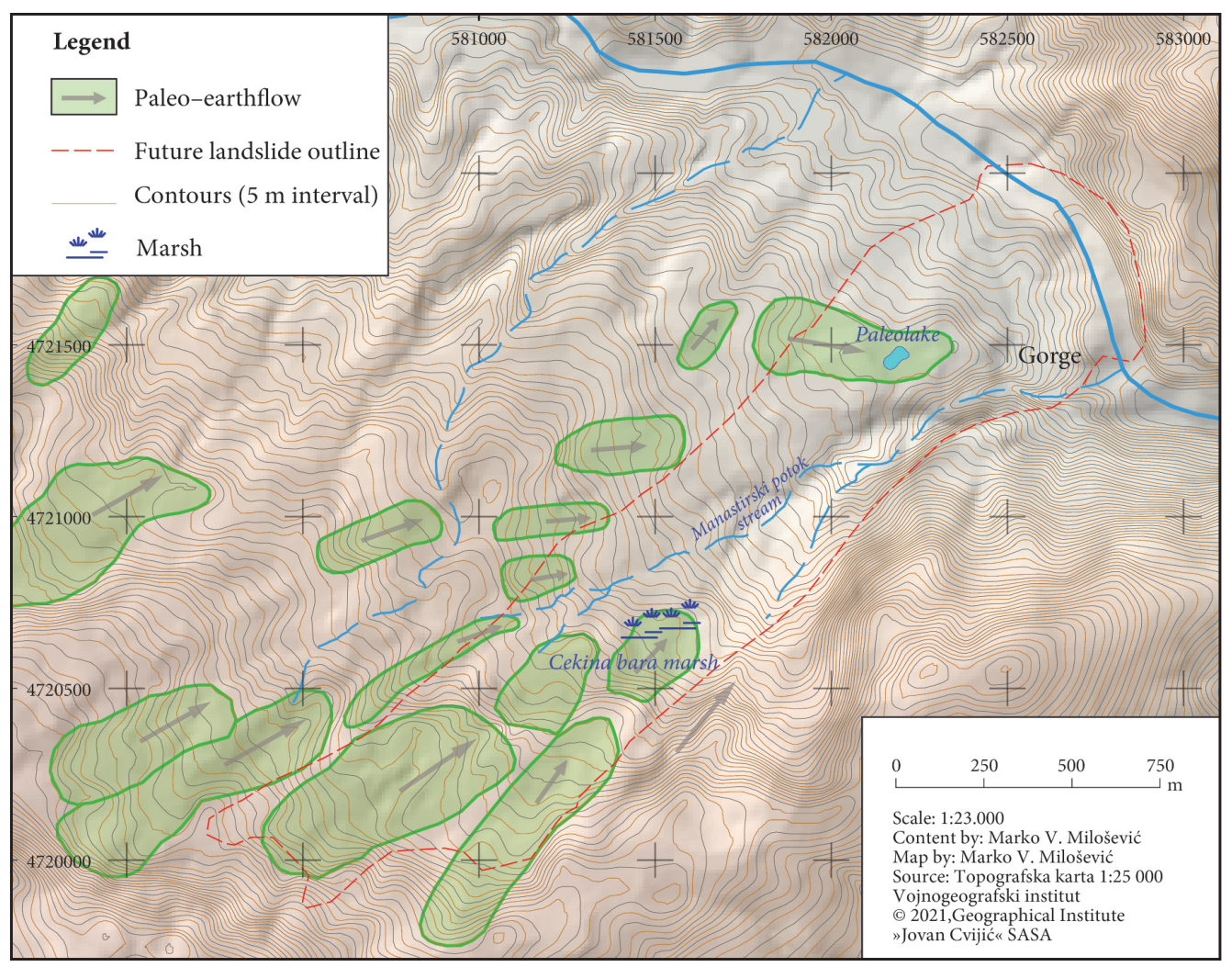

Figure 4: Paleo-earthflows on the right side of the valley of the Jovačka River (1971 situation), where the 1977 landslide was later formed.

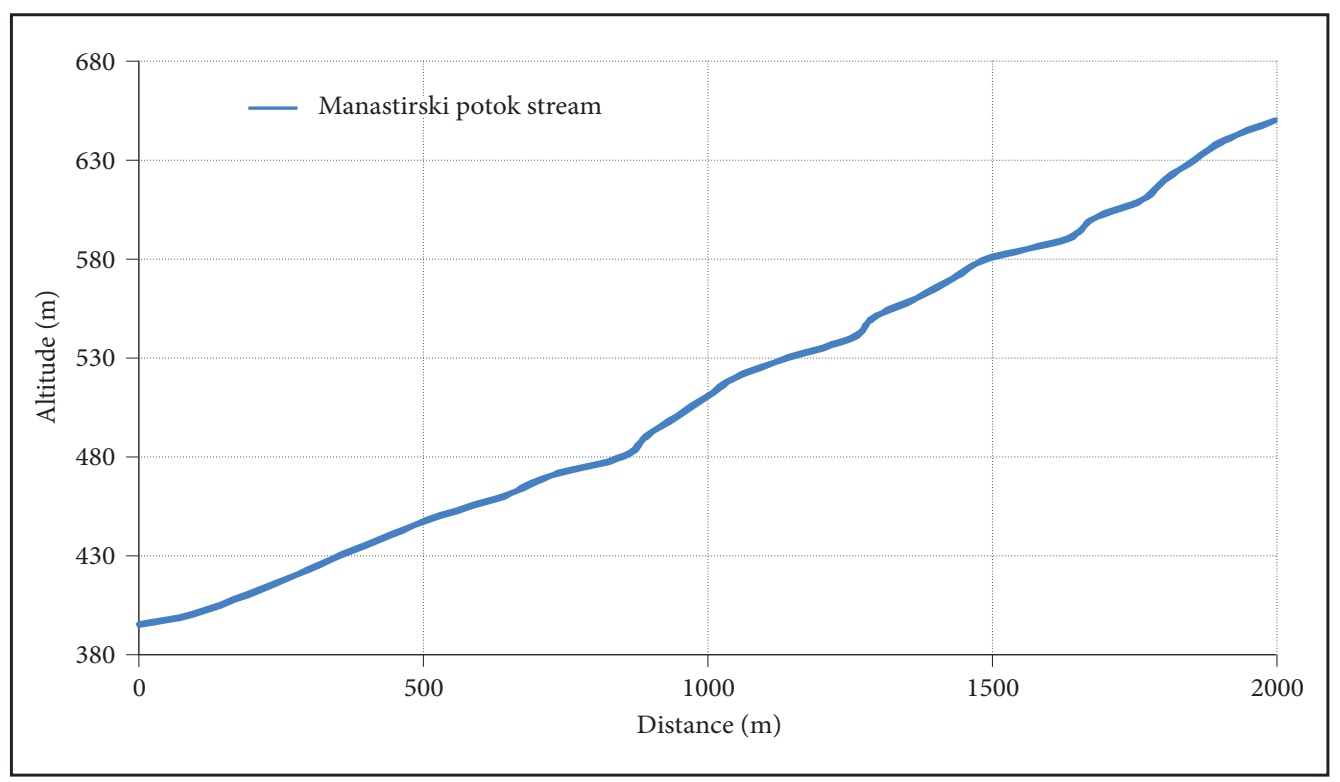

Figure 5: Longitudinal profile of the stream Manastirski Potok. 
Through the palaeogeographic evolution of the area during the Tertiary, it is possible to identify some of the lithological predispositions for the formation of the Jovac landslide. As mentioned above, synchronous deposition of terrigenous and volcanoclastic sediments took place during the Middle Miocene (Jovanović and Novković 1988). This sedimentary-volcanogenic unit represented by clays, sands, pebbles, volcanic ash, lapilli, tuff, volcanic agglomerates and volcanic blocks subsequently becomes an ideal environment for the formation of the Jovac landslide. Lithologically, the southwestern hinterland of the landslide consists of dacites (the Gradište and Ostrovica peaks) (Vukanović et al. 1970), while pyroclastites such as volcanic breccias and agglomerates, as well as tuff sandstones and tuffs (Kremen Ridge) are located to the east and southeast (Babović et al. 1977). The contact of these lithological units with the sedimentary-volcanogenic unit determined the boundaries of the subsequent Jovac landslide.

The hydrogeological characteristics of pyroclastites, which topographically gravitate towards the landslide, are different than those of the dacites. Their permeability is extremely low and the regolith is rather thin. Considering the morpho-hydrological criteria, there are two significant topographic units. The first is the surface catchment area of the Jovac landslide and the second is the endorheic area within it. The landslide catchment area includes not only the landslide body and hinterland of the scar, but also the lateral areas that morphologically gravitate towards the main landslide body (Figure 6).

Regarding the hydrogeological characteristics of the lithological units, two zones can be distinguished: feeding zone and collection zone. The feeding zone is the landslide body (Miocene sedimentary-volcanogenic

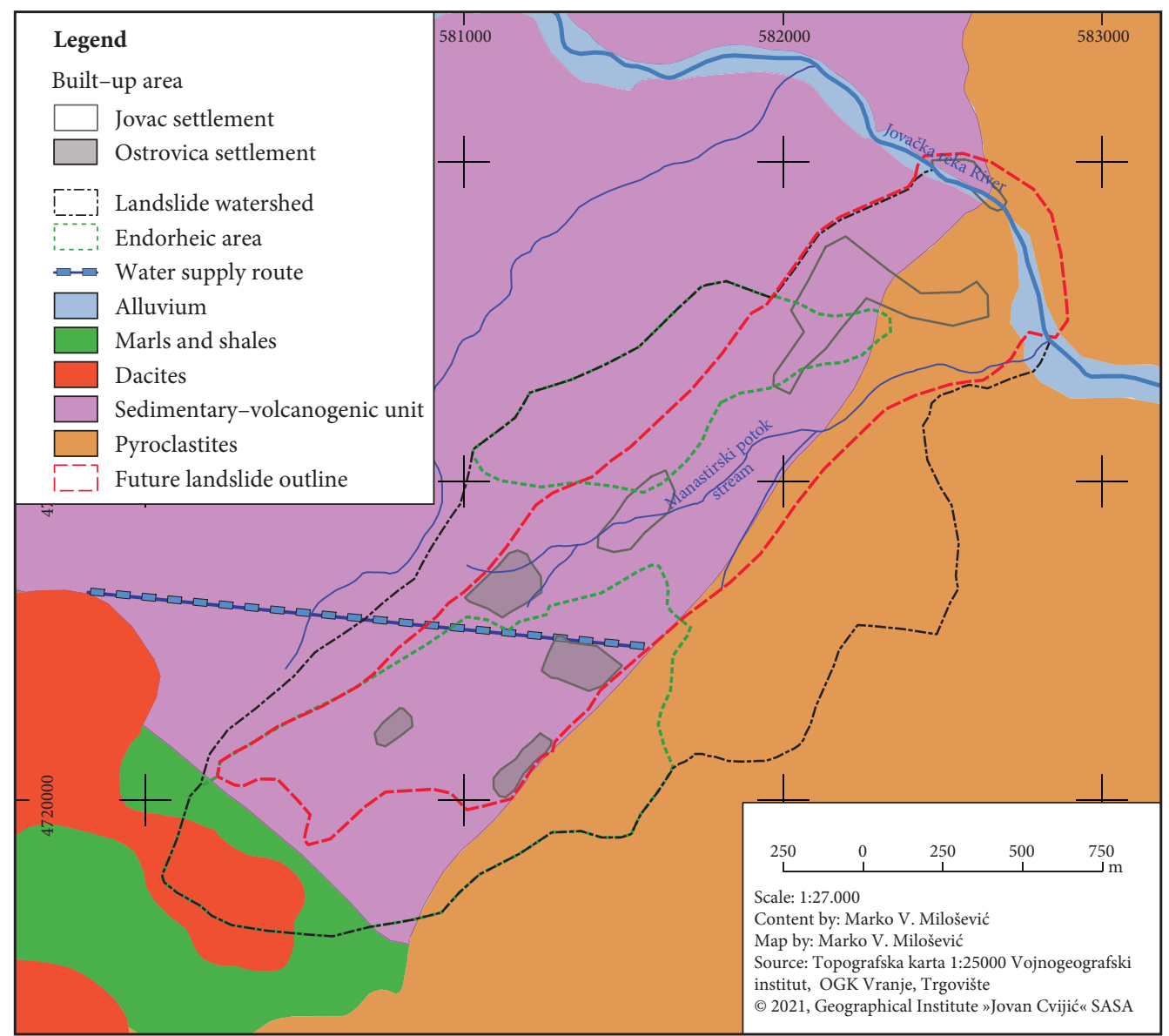

Figure 6: Predispositions for the development of the Jovac landslide. 
unit), which has the role of hydrocollector (reservoir) and is fed by infiltration of atmospheric and surface water. Water flowed from the impermeable areas of the dacites and pyroclastites towards the landslide body. This was an additional factor in increasing the amount of water received by the topographic surface. The total catchment area of the Jovac landslide was $3.06 \mathrm{~km}^{2}$, of which $52 \%$ was the area of landslide itself.

Another morpho-hydrographic feature is the occurrence of endorheic areas, which were detected on $48 \%$ of the catchment area (Table 4). This means that the water of $1.47 \mathrm{~km}^{2}$ did not drain superficially but infiltrated into the ground. The endorheic areas were divided into two areas. The first $\left(1.07 \mathrm{~km}^{2}\right.$; of which $0.519 \mathrm{~km}^{2}$ on the landslide) included the upper part of the slope, immediately below the Ostrovica peak, while another of $0.4 \mathrm{~km}^{2}$ (of which $0.107 \mathrm{~km}^{2}$ on the landslide) included the area around a palaeolake, to the northwest from the Manastirski Potok Gorge.

Table 4: Hydrographic characteristics of the catchment area.

\begin{tabular}{lcccc}
\hline Hydrography & \multicolumn{2}{c}{ Catchment area } & \multicolumn{2}{c}{ Jovac landslide } \\
\hline & $\mathrm{km}^{2}$ & $\%$ & $\mathrm{~km}^{2}$ & $\%$ \\
\hline Exorheic & 1.59 & 52 & 0.96 & 60 \\
Endorheic & 1.47 & 48 & 0.62 & 40 \\
SUM & 2.84 & 100 & 1.58 & 100 \\
\hline
\end{tabular}

In the case of the Jovac landslide, human impact is associated with the increase of the slope catchment area. In other words, the total amount of water that a given area receives comes not only from its topographic catchment, but also from other catchments. The inhabitants of the village of Ostrovica built a water-supply system that directed the water from below the Oštra Čuka (1040 m) (Figure 6). Despite the fact that this area is not morphologically directed to the future landslide body, the human activity additionally increased the water balance of the slope. The water supply system was of gravitational and flow-through type, which resulted in water consumption exceeding the actual needs of the population (Lazarević 2000). This was certainly not the main, but only an additional factor in triggering the landslide. The main anthropogenic factor was the permanent humidification of the ground in the built area zone, due to the water supply system which transferred the water from the neighboring catchment, area thus increasing the water input.

\subsection{Morphometric characteristics of the Jovac landslide}

The landslide boundary was determined based on the spatial distribution of elevations of the topographic surface, as explained in the Chapter 3. The topographic surface with no or with minimal differences was declared as the landslide boundary. Thus, a polygon similar to the one defined by Petrović and Stanković (1981) was formed. The boundaries outline the elongated area with an area of $1.58 \times 10^{6} \mathrm{~m}^{2}$. The maximum length of the landslide is $3,000 \mathrm{~m}$, while the widthe varies from $490 \mathrm{~m}$ to $670 \mathrm{~m}$. Two distinct continuous areas are visible, representing the values of the elevation change differences. The smaller area $\left(0.62 \times 10^{6} \mathrm{~m}^{2}\right)$ is located in the highest part of the landslide. It is characterised by the lowering of the previous topographic surface in the interval from -1 to $-45 \mathrm{~m}$. In the middle and hypsometrically lowest part of the slope $\left(0.96 \times 10^{6} \mathrm{~m}^{2}\right)$ (Figure 8A), the changes indicate the increased elevation of the topographic surface. The values are in the interval from +1 to $+51 \mathrm{~m}$. The boundary between these two areas is a narrow belt where the elevation change was not detected or is negligible (Figure 7).

In the area of lowering of the previous topographic surface, the differences are positioned concentrically, and increase towards the interior. In the central part the highest extent of the topographic surface lowering was $-45 \mathrm{~m}$. The distribution of the differences in elevation is very uneven. The greatest change is recorded at the former gorge of the Manastirski Potok Stream. The values of topographic elevations increase fall in the interval from +31 to $+51 \mathrm{~m}$. Outside this zone, the accumulation reaches $+30 \mathrm{~m}$ only in some places. Other values of topographic increase are distributed in various locations.

By analysing the topographic elevation difference for each DTM cell $(30 \times 30 \mathrm{~m})$, the volume of landslide was determined. The estimated volume of the depleted ground, where the surface was lowered is $12.45 \times 10^{6} \mathrm{~m}^{3}$. The volume of colluvium in the zone of topographic surface elevation increase is $11.6 \times 10^{6} \mathrm{~m}^{3}$, which is $4 \%$ less than the volume of depleted ground (Figure 8B). 
Marko V. Milošević, Dragoljub Štrbac, Jelena Ćalić, Milan Radovanović, Detection of earthflow dynamics using ...

Legend

ᄃ- L Landslide boundary

- Contours at $20 \mathrm{~m}$

$\square$ Lake outline

Elevation differences $(\mathrm{m})$

$\square-45$

$\square-44.9--35$

$\square-34.9--25.0$

$\square-24.9--15.0$
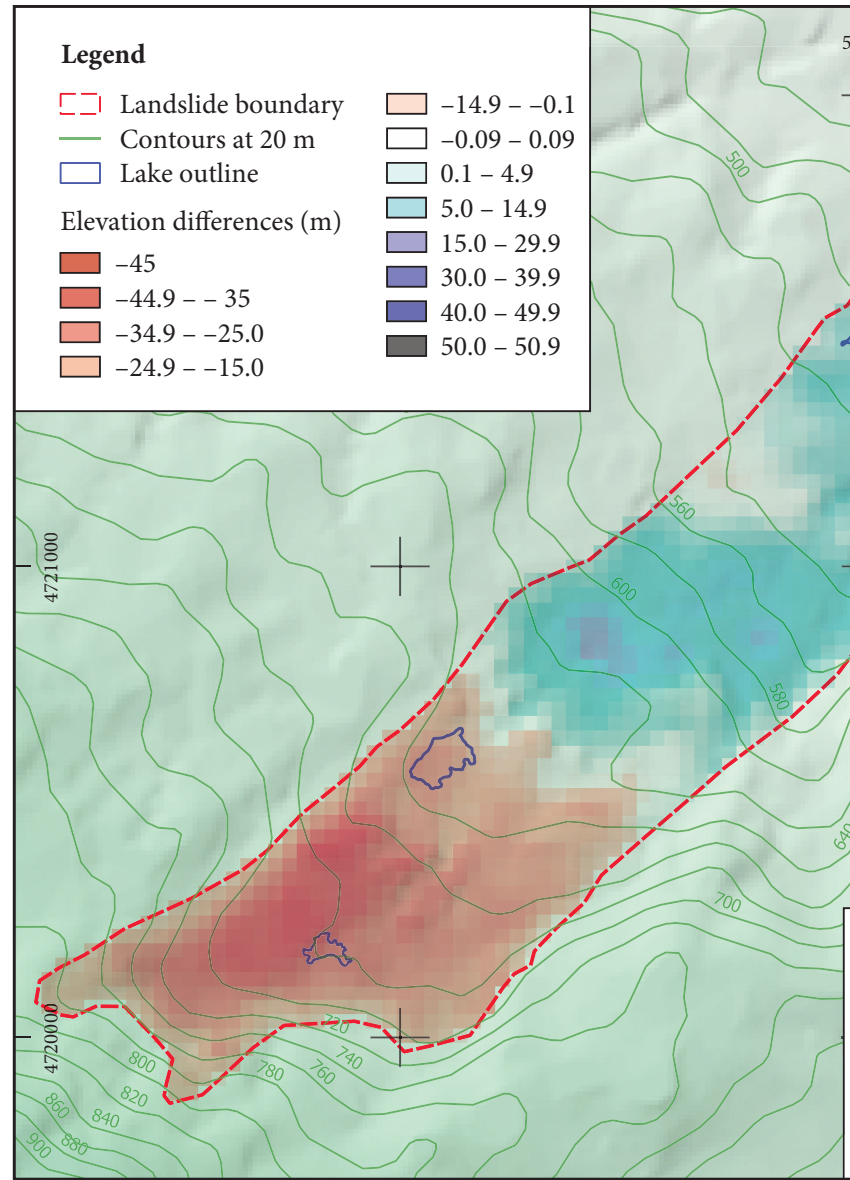

Scale: 1:21.000
Content by: Marko V. Milošević, Dragoljub Štrbac
Map by: Marko V. Milošević
Source: Topografska karta 1:25 000
Vojnogeografski institut, SRTM
(c) 2021, Geographical Institute
»ovan Cvijić« SASA

Figure 7: Elevation differences of the topographic surface of the Jovac landslide (contours refer to the present topographical surface).

As a result of large denivelation of the topographic surface on the landslide body, several small lake basins have formed. They are permanently filled with water. Of the six lakes, five are located on the landslide body - two in the depletion zone and three in the accumulation zone (Figure 7). The sixth and largest lake is the Jovac Lake, formed by the landslide dam of the Jovačka Reka River.

Table 5: Extreme and average morphometric characteristics of pre-sliding and post-sliding topographic surfaces.

\begin{tabular}{llcccc}
\hline \multirow{3}{*}{ Pre-sliding } & & Elevation $(\mathrm{m})$ & Slope $\left({ }^{\circ}\right)$ & Curvature & Aspect $\left({ }^{\circ}\right)$ \\
\cline { 2 - 6 } & Min & 380 & 0.0 & -5.046 & \\
\cline { 2 - 6 } & Max & 807 & 87.0 & 5.046 & 110 \\
\cline { 2 - 6 } & Average & 568 & 11.0 & 0.015 & \\
\hline Post-sliding & Min & 390 & 0.0 & -0.342 & 101 \\
\cline { 2 - 6 } & Max & 793 & 43.0 & 0.361 & \\
\cline { 2 - 6 } & Average & 567 & 9.6 & 0.014 & \\
\hline
\end{tabular}


a)

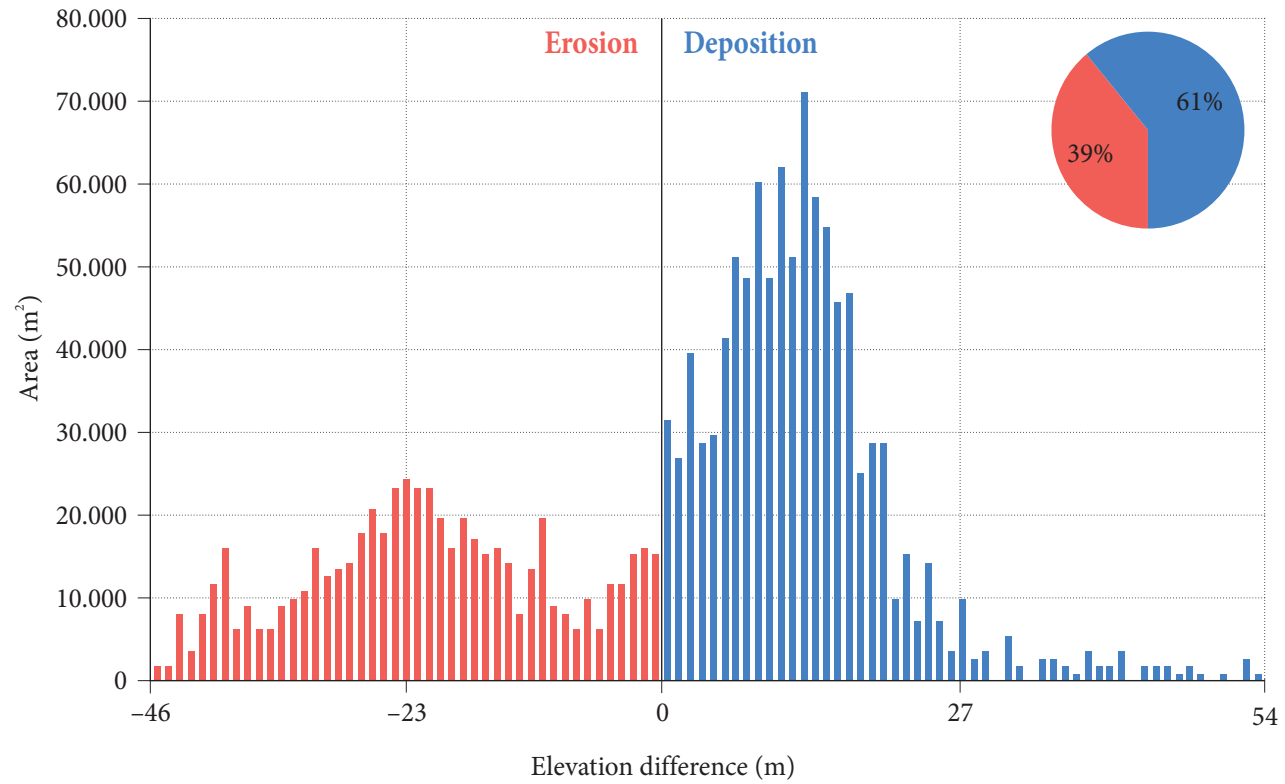

b)

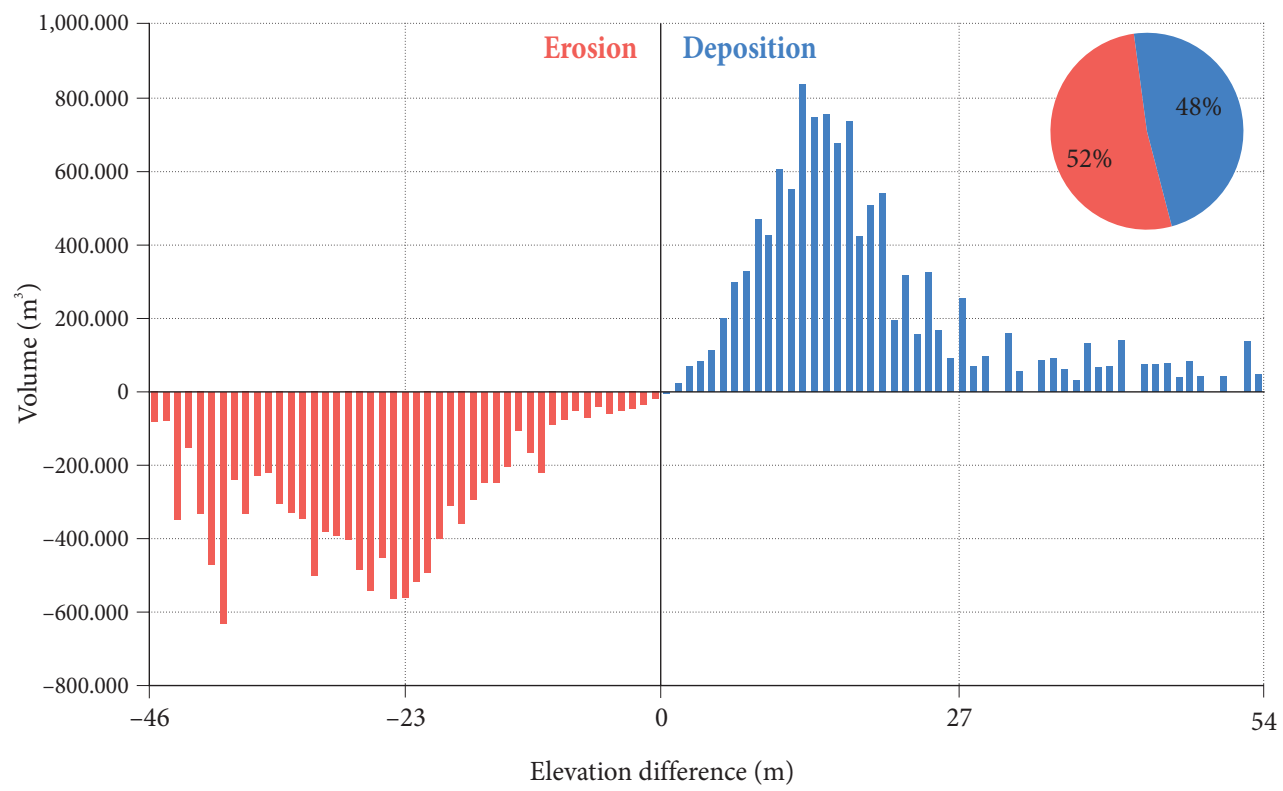

Figure 8: Distribution of elevation differences on the topographic surface $(A)$ and distribution of volumes (B). 
Marko V. Milošević, Dragoljub Štrbac, Jelena Ćalić, Milan Radovanović, Detection of earthflow dynamics using ...

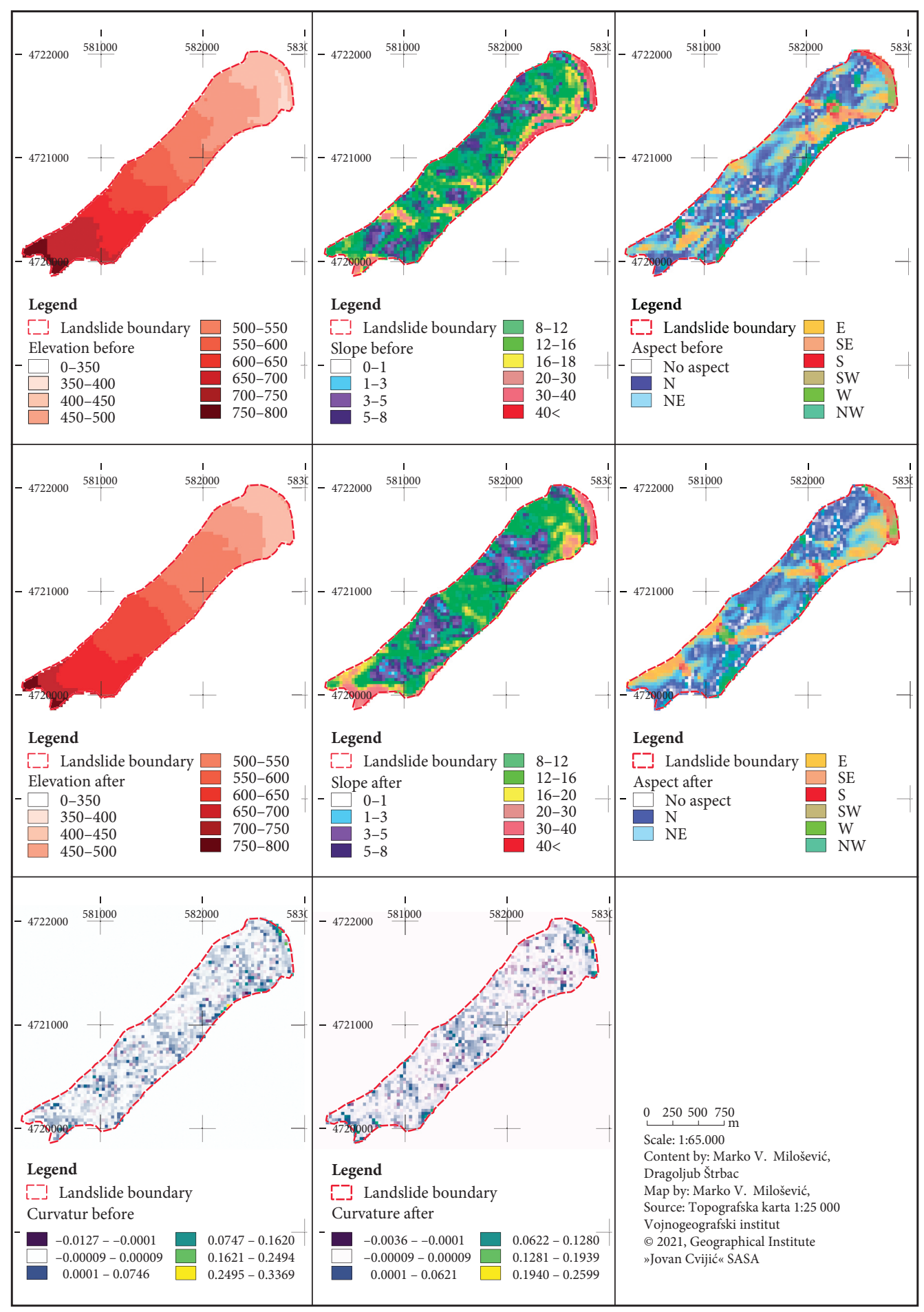

Figure 9: Morphometric characteristics before and after the sliding process. 


\section{Discussion}

Although the descriptions of Jovac the mechanisms of movement of the Jovac landslide by Lazarević (1977) and Petrović and Stanković (1981) fit into the category of »flow «, the authors explicitly referred to the movement as sliding. The analysis of the planar form of the Jovac landslide, where the length is much greater than the width, according to the nomenclature of Varnes, modified by Hungr et al. (2014) and the international classification of landslides according to the movement mechanism IAEG (1991-1992), indicate that the flow-associated elements are also present.

This statement can be analysed by three indicators based on the analysis of two DTMs, and related to the elevation differences of the situations before and after the slide.

The first indicator is runoff. It shows how many cells $(30 \times 30 \mathrm{~m}$ pixels $)$ gravitate to an observed cell, i.e. how large is the "catchment area " of each cell. For this analysis, only the values obtained from the presliding DTM were considered. The second indicator is the elevation difference of two DTMs for each selected cell (negative or positive, indicating depletion or accumulation). The third indicator is the current elevation of a cell, the elevation after the sliding process.

Comparative analysis of these indicators was a valuable tool in geomorphological reconstruction of the area. The cross-section in the depletion zone (with lowering of the topographic surface) showed that the depletion peaks do not follow the peaks of the runoff capacity. The runoff peaks are directly proportional to the drainage lines. This indicates that the sliding process in the upper part of the landslide was independent of the morphology of the topographical surface (profile B-Bo in the Figure 10A). The depletion zone almost completely overlaps with the endorheic area and conditions for water saturation of soil and rock are favourable (Lollino, Giordan and Allasia 2014).

The cross sections in the accumulation zone show a clearly different situation. Profile C-Co shows a matching of the runoff peaks, but not so many conspicuous peaks in the increase of the topographic values (Figure 10B). The same is seen on the $\mathrm{D}-\mathrm{Do}$ profile, with slightly better visible peaks compared to C-Co, thanks to its lower position on the slope (Figure 10C). This feature may indicate that the highest accumulation of the material occurred along the drainage lines. In other words, the morphology of the pre-sliding surface determined the movement of colluvial material from the depletion zone (upper slope) through the accumulation zone (middle and lower zones).

To prove the assumption that in the lower part of the landslide the flow followed the stable palaeotopographic surface, it was necessary to include the third indicator, the elevation of the cells after the slide (Figure 11D). Figure 11D shows that the convex portions of the current topographic surface overlap with the peaks of runoff and accumulation. A convex profile of the topographic surface in the earthflow accumulation zones was also pointed by Soeters and van Westen (1996). This undoubtedly proves that the colluvial material from the depletion zone continued to move downwards following the pre-existing morphology of the middle and lower parts of the slope. The underlying rock was certainly stable, thanks to the pyroclastite zone on the northeast side. This type of movement was a consequence of supersaturation by water, which decreased the viscosity of the colluvium and allowed it to follow the slope morphology. This also explains the asymmetry in the colluvium thickness, which is greatest in the zone of the former gorge of Manastirski Potok.

Based on the presented relationships between the colluvium and topographic surface we conclude that the Jovac landslide has elements of earthflow movement. According to the ICL classification (Internet 1), the Jovac earthflow is in the category of large landslides $\left(\geq 10^{6} \mathrm{~m}^{3}\right)$. In Serbia, landslides with similar volume and lithology usually occur along the banks of large rivers and their movement mechanisms are rotational and planar. The right bank of the Danube River hosts the Bocke landslide, Krčedin landslide (Mészáros 2013), Cigansko Brdo (Janjić 1996), Rujište (Lazarević 1957; Janjić 1996), Provalija (Luković 1951), while the Umka and Duboko landslides are located on the right bank of the Sava River (Abolmasov et al. 2014).

Figure 10: Relationship between discharge and elevation differences along cross sections (see also Figure 1). $>$ p. 202

Figure 11: Model of the Jovac landslide adapted from Petrović and Stanković (1981) (A); Iongitudinal profile of the Jovac landslide (B); cross section in the topographic decrease zone (C); cross section in the increase zone of Manastirski Potok Gorge (D) (see also Figure 1). > p. 203 
Marko V. Milošević, Dragoljub Štrbac, Jelena Ćalić, Milan Radovanović, Detection of earthflow dynamics using ...

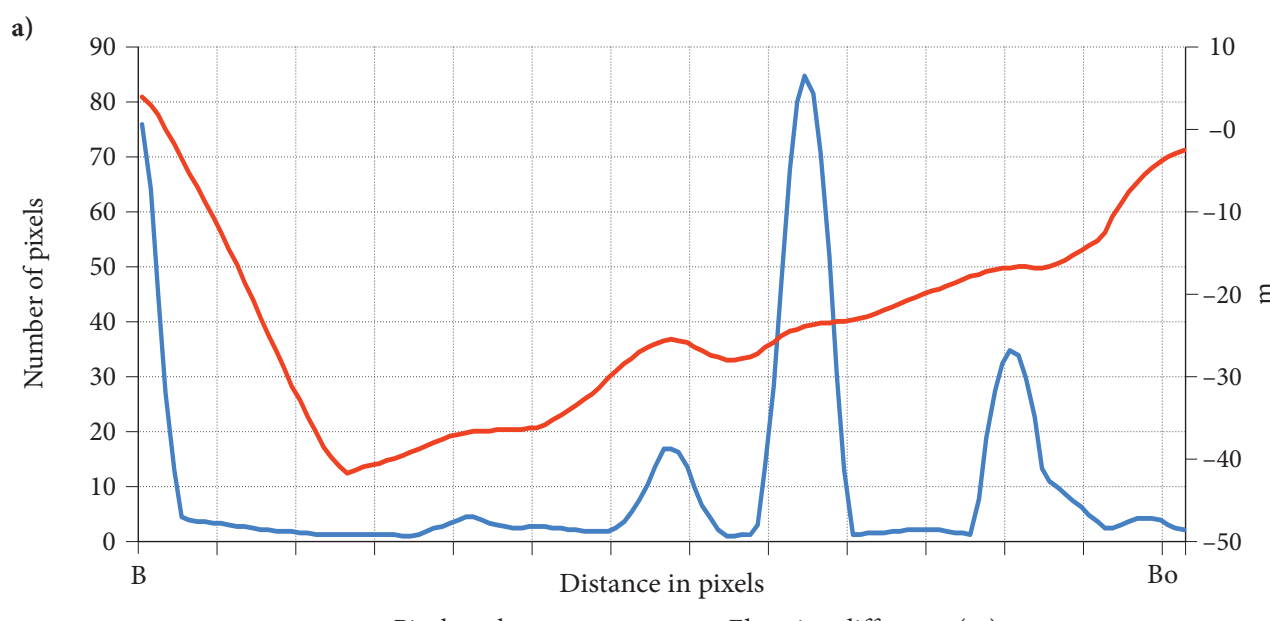

b)

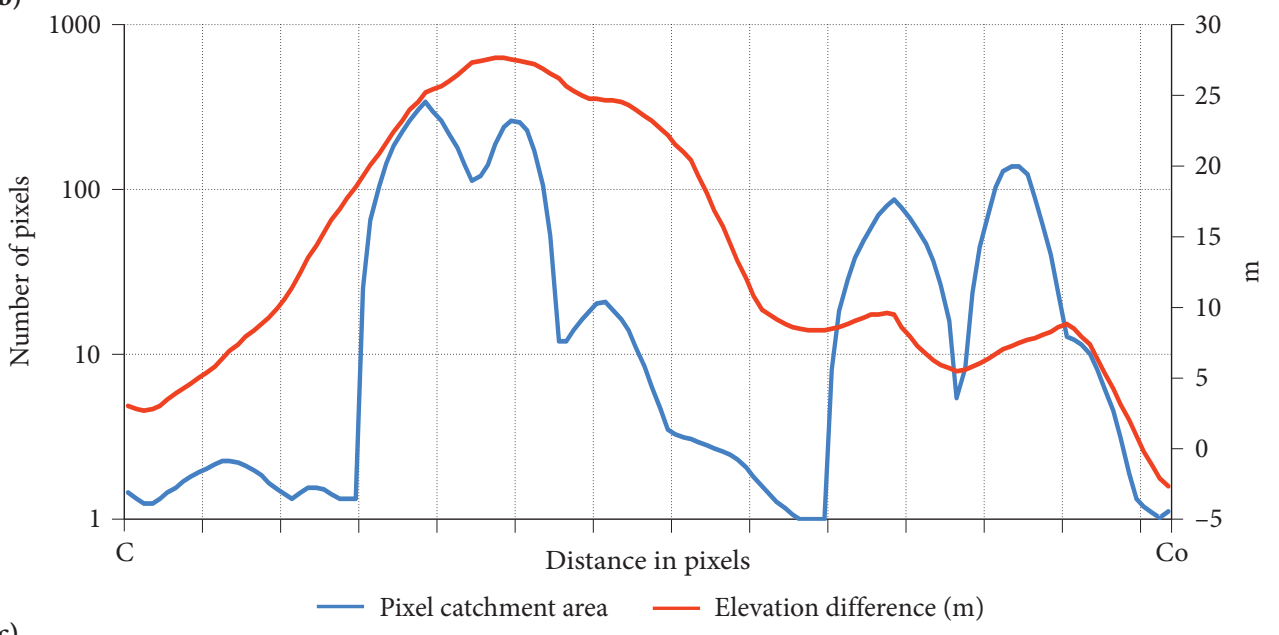

c)

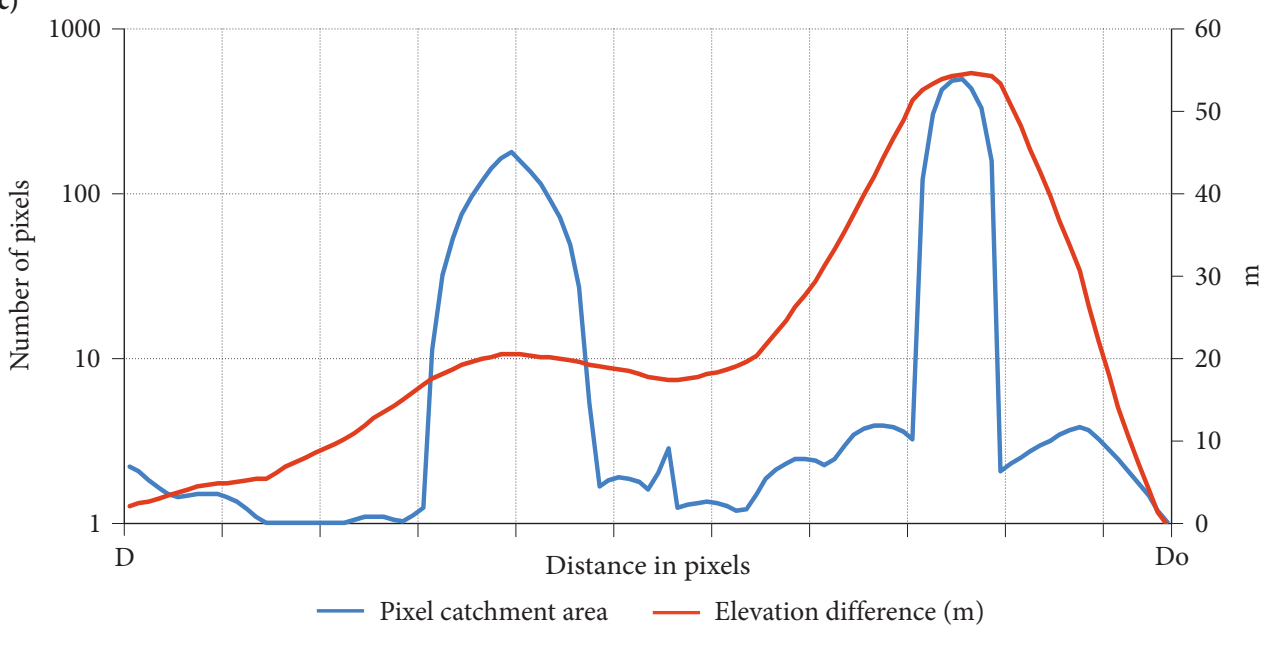


a)

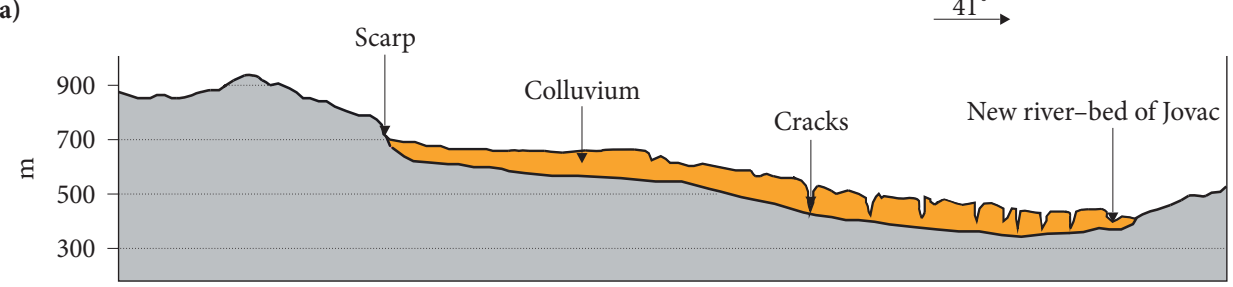

b)

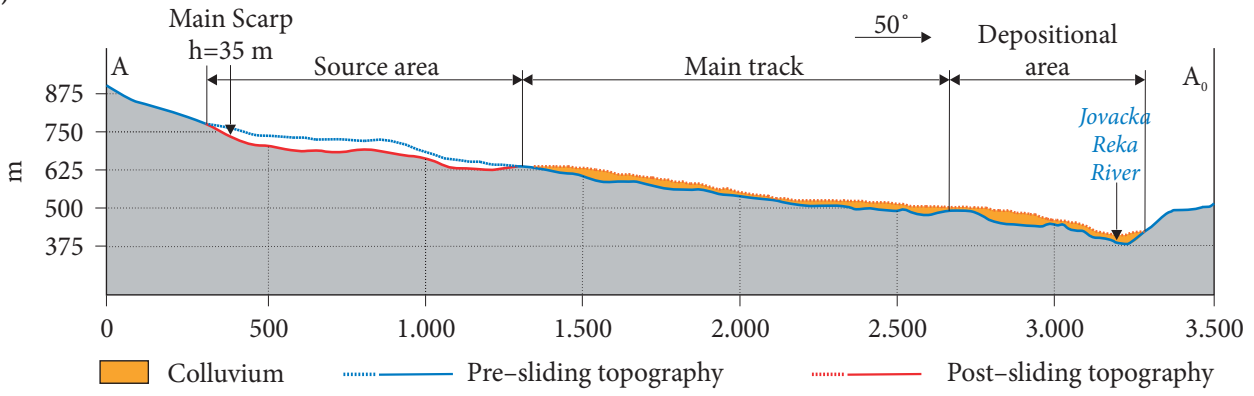

c)

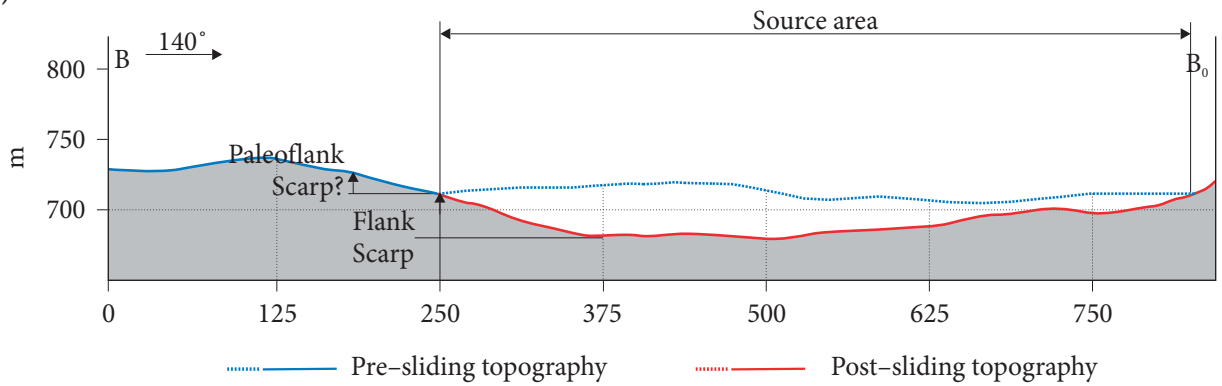

d)

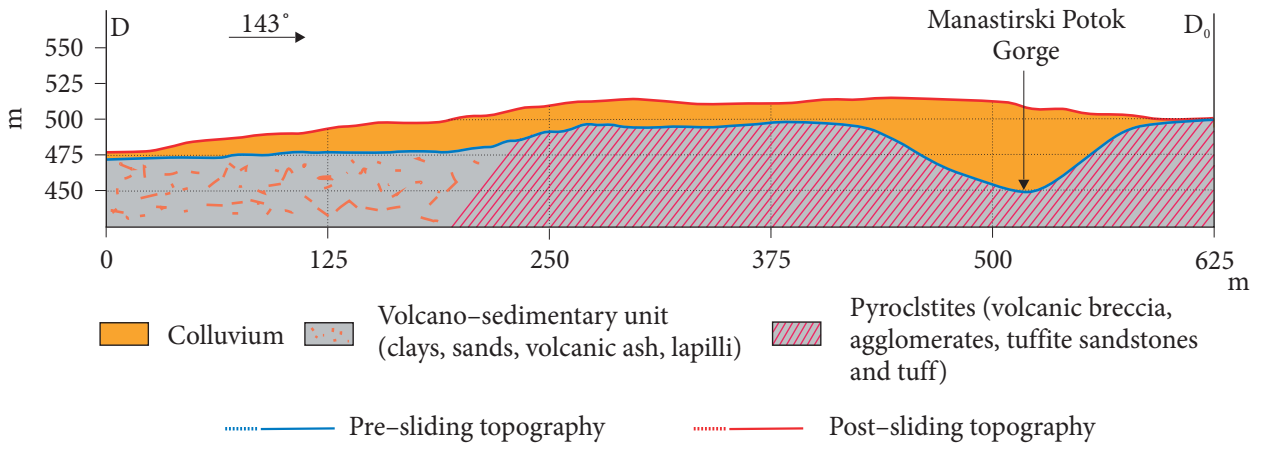




\section{Conclusion}

According to the systematization of Varnes (1978) and Cruden and Varnes (1996), the mechanism of the Jovac landslide colluvium movement can be determined as flowing. In terms of material (criteria of Varnes 1978), it belongs to the category of earth, containing high proportion of particles about $2 \mathrm{~mm}$ in size. Using the modified Varnes (1978) classification of landslides (Hungr, Leroueil and Picarelli 2014), the Jovac landslide belongs to the category of earthflow. Its estimated volume is $11.6 \times 10^{6} \mathrm{~m}^{3}$, which is a significant difference compared to the earlier estimates of $150 \times 10^{6} \mathrm{~m}^{3}$ (Lazarević 1977; Petrović and Stanković 1981). The reason for such a difference lies is that the earlier researchers had rather poor spatial data, mostly collected by fieldwork observations. We believe that the exceptional size of the landslide and the degree of damage may have influenced the earlier researchers to somewhat subjective conclusions.

In determining the landslide contour, two DTMs were used, one with the situation before the landslide and one with the situation after the landslide. In order to explain that the elevation differences between them are the consequences of the sliding process, it was necessary to define the procedure to avoid technical errors. Possible errors could be related to the incorrect overlapping of two DTMs and to the possible presence of systematic errors due to different types of elevation data acquisition. After completing the testing, we obtained the exact elevation differences between two DTMs caused by the sliding process.

The use of small- and medium-resolution DTMs, in this case $30 \times 30 \mathrm{~m}$ (Corsini et al. 2009; Hu et al. 2019), can be a relevant data source for landslide studies, provided that the dimensions of the landslide are large enough to be visible in a DTM. The DTM resolution used makes the study comparable worldwide, as both EU and global DTMs use this resolution. In the case of the Jovac landslide, the pre-slide data were obtained from the topographic map $1: 25,000$. The input data determined the resolution of $30 \times 30 \mathrm{~m}$. Judging by the area of the Jovac earthflow $\left(1.58 \mathrm{~km}^{2}\right)$ and the volume $\left(11.6 \times 10^{6} \mathrm{~m}^{3}\right)$, we conclude that the DTM at this resolution contains the information relevant to the earthflow formation process. We also conclude that the analysis of the elevation differences of the topographic surface before and after the landslide is an appropriate method to study earthflows (Fernández et al. 2011; Giordan et al. 2013). The endorheic character of the paleotopographic surface, determined by the previous earthflow process, was one of the conditions that strongly contributed to the reactivation of the Jovac earthflow in 1977.

ACKNOWLEDGMENTS: The authors would like to sincerely thank an anonymous reviewer for his valuable comments on the manuscript, which demonstrate the very responsible way in which the review process was handled.

\section{References}

Abolmasov, B., Milenković, S., Marjanović, M., Đurić, U., Jelisavac, B. 2015: A geotechnical model of the Umka landslide with reference to landslides in weathered Neogene marls in Serbia. Landslides 12. DOI: https://doi.org/10.1007/s10346-014-0499-4

Amundsen, J., Johnson, S., Rouse, K., Wang, H. 2010: Using LiDAR-derived DTM's to delineate and characterize landslides in Northern Kentucky and Hamilton County, Ohio. Internet: http://www.trishock.com/ acaDTMic/pdf/lidar_landslides.pdf (22. 12.2020).

Ardizzone, F., Cardinali, M., Galli, M., Guzzetti, F., Reichenbach, P. 2007: Identification and mapping of recent rainfall-induced landslides using elevation data collected by airborne Lidar. Natural Hazards and Earth System Sciences 7-6. DOI: https://doi.org/10.5194/nhess-7-637-2007

Babović, M., Roglić, Č., Avramović, V., Marić, S. 1977: Tumač za Osnovnu geološku kartu 1: 100,000, list Trgovište. Savezni geološki zavod, Beograd.

Chen, Z., Ye, F., Fu, W., Ke, Y., Hong, H. 2020: The influence of DTM spatial resolution on landslide susceptibility mapping in the Baxie River basin, NW C-hina. Natural Hazards: Journal of the International Society for the Prevention and Mitigation of Natural Hazards 101-3. DOI: https://doi.org/10.1007/s11069020-03899-9

Claessens, L., Heuvelink, G. B. M., Schoorl, J. M., Veldkamp, A. 2005: DEM resolution effects on shallow landslide hazard and soil redistribution modelling. Earth Surface Process Landforms 30-4. DOI: https://doi.org/10.1002/esp.1155 
Conoscenti, C., Ciaccio, M., Caraballo-Arias, N. A., Gómez-Gutiérrez, Á., Rotigliano, E., Agnesi, V. 2015: Assessment of susceptibility to earth-flow landslide using logistic regression and multivariate adaptive regression splines: A case of the Belice River basin (western Sicily, Italy). Geomorphology 242. DOI: https://doi.org/10.1016/j.geomorph.2014.09.020

Corsini, A.; Borgatti, L.; Cervi, F.; Dahne, A.; Ronchetti, F., Sterzai, P. 2009: Estimating mass-wasting processes in active earth slides - earth flows with time-series of High-Resolution DEMs from photogrammetry and airborne LiDAR. Natural Hazards and Earth System Sciences 9. DOI: https://doi.org/ 10.5194/nhess-9-433-2009

Cruden, D. M. 1991: A simple definition of a landslide. Bulletin of the International Association of Engineering Geology 43. DOI: https://doi.org/10.1007/BF02590167

Cruden, D. M., Varnes, D. J. 1996: Landslide types and processes. Landslides: Investigation and Mitigation. Washington.

Cvetković, V.; Šarić, K., Mladenović, A. 2019: Magmatizam i metamorfizam. Geohemijsko-geodinamička perspektiva. Beograd.

Dietrich, W. E. and Montgomery, D. R 1998: SHALSTAB: A digital terrain model for mapping shallow landslide potential. NCASI - National council of the paper industry for air and stream improvement, 1998.

Đomlija, P. 2018: Identification and classification of landslides and erosion phenomena using the visual interpretation of the Vinodol valley digital elevation model. Ph.D. thesis, University of Zagreb. Zagreb.

Fernández, T., Pérez, J. L., Cardenal, F. J., Delgado, J., Irigaray, C., Chacón, J. 2011: Evolution of a diachronic landslide by comparison between different DEMs obtained from digital photogrammetry techniques in Las Alpujarras (Granada, Southern Spain). Internet: https://www.isprs.org/proceedings/2011/gi4dm/ PDF/OP69.pdf (18.10.2020).

Fernández, T., Pérez, J. L., Colomo, C., Cardenal, J., Delgado, J., Palenzuela, J. A., Irigaray, C., Chacón, J. 2017: Assessment of the evolution of a landslide using digital photogrammetry and LiDAR techniques in the Alpujarras Region (Granada, Southeastern Spain). Geosciences 7-2. DOI: https://doi.org/10.3390/ geosciences7020032

Gigović, L. J. 2010: Digitalni modeli visina i njihova primena u vojnoj analizi terena. Vojnotehnički glasnik 58-2.

Giordan, D., Allasia, P., Manconi, A., Baldo, M., Santangelo, M., Cardinali, M., Corazza, A. et al. 2013: Morphological and kinematic evolution of a large earthflow: The Montaguto landslide, southern Italy. Geomorphology 187. DOI: https://doi.org/10.1016/j.geomorph.2012.12.035

Govedarica, M., Borisov, M. 2011: The Analysis of data quality on topographic maps. Geodetski vestnik $55-4$.

Guzzetti, F., Mondini, A. C., Cardinali, M., Fiorucci, F., Santangelo, M., Chang K. T. 2012: Landslide inventory maps: New tools for an old problem. Earth-Science Reviews 112-1,2. DOI: https://doi.org/10.1016/ j.earscirev.2012.02.001

Hrvatin, M., Perko, D. 2005: Differences between 100-meter and 25-meter digital elevation models according to types of relief in Slovenia. Acta geographica Slovenica 45-1. DOI: https://doi.org/10.3986/AGS45101

Hu, S., Qiu, H., Pei, Y., Cui, Y., Xie, W., Wang, X.; Yang, D. et al. 2019: Digital terrain analysis of a landslide on the loess tableland using high-resolution topography data. Landslides 16. DOI: https://doi.org/ 10.1007/s10346-018-1103-0

Hungr, O., Leroueil, S., Picarelli, L. 2014: The Varnes classification of landslide types, an update. Landslides 11. DOI: https://doi.org/10.1007/s10346-013-0436-y

Internet 1: http://iplhq.org/ (29. 9. 2021).

Jaboyedoff, M., Oppikofer, T., Abellán, A., Derron, M. H., Loye, A. Metzger, R., Pedrazzini, A. 2012: Use of LIDAR in landslide investigations: A review. Natural Hazards 61-1. DOI: https://doi.org/10.1007/ s11069-010-9634-2

Janjić, I. 1996: Geneza i svojstva klizišta u neogenim sedimentima južnog oboda Panonskog basena. M.Sc. thesis, University of Belgrade. Belgrade.

Jevremović, D., Sunarić, D., Kostić, S. 2011: Landslide and rockfall induced lakes in Serbia. Tehnika 66-5.

Jovanović, O., Novaković, M. 1988: Litološke odlike tercijarnih naslaga Vranjsko-pčinjskog basena. Vesnik geološkog zavoda 44 .

Keefer, D. K., Johnson, A. M. 1983: Earth flows: Morphology, mobilization and movement. Washington. 
Marko V. Milošević, Dragoljub Štrbac, Jelena Ćalić, Milan Radovanović, Detection of earthflow dynamics using ...

Lazarević, R. 1957: The relief of the immediate Danube basin between Grocka and Smederevo. Journal of the Geographical Institute »Jovan Cvijić« SASA 13.

Lazarević, R. 1977: Jovačko kliziste . Erozija 8.

Lazarević, R. 2000: Klizišta. Beograd.

Lee, S., Ryu, J. H., Won, J. S., Park, H. J. 2004: Determination and application of the weights for landslide susceptibility mapping using an artificial neural network. Engineering Geology 71-3,4. DOI: https://doi.org/10.1016/S0013-7952(03)00142-X

Lollino, P., Giordan, D., Allasia, P. 2014: The Montaguto earthflow: A back-analysis of the process of landslide propagation. Engineering Geology 170. DOI: https://doi.org/10.1016/j.enggeo.2013.12.011

Luković, T. M. 1951: Važniji tipovi naših klizišta i mogućnosti njihovog saniranja. Geološki Vesnik 9.

Mahalingam, R., Olsen, M. J. 2016: Evaluation of the influence of source and spatial resolution of DEMs on derivative products used in landslide mapping. Geomatics, Natural Hazards and Risk 7-6. DOI: https://doi.org/10.1080/19475705.2015.1115431

McKean, J., Roering, J. 2004: Objective landslide detection and surface morphology mapping using high-resolution airborne laser altimetry. Geomorphology 57-3,4. DOI: https://doi.org/10.1016/ S0169-555X(03)00164-8

Mészáros, M. 2013: Spatial analysis of geohazard on the Fruška Gora mountain. Ph.D. thesis, University of Szeged. Szeged.

Pavlović, R., Ćalić, J., Djurović, P., Trivić, B., Jemcov, I. 2012: Recent landform evolution in Serbia. Recent Landform Evolution. The Carpatho-Balkan-Dinaric Region. Dordrecht.

Petrović, V., Stanković, S. 1981: Veliko klizište u selu Jovac. Simpozijum istraživanje i sanacija klizišta. Beograd.

Prelević, D., Foley, S. F., Romer, R. L., Cvetković, V., Downes, H. 2005: Tertiary ultrapotassic volcanism in Serbia: Constraints on petrogenesis and mantle source characteristics. Journal of Petrology 46-7. DOI: https://doi.org/10.1093/petrology/egi022

Pre-processing algorithms and landslide modelling on remotely sensed DEMs. Geomorphology 113-1,2. DOI: https://doi.org/10.1016/j.geomorph.2009.03.023

Rogers, D. J., Chung, J. 2016: Mapping earthflows and earthflow complexes using topographic indicators. Engineering Geology 208. DOI: https://doi.org/10.1016/j.enggeo.2016.04.025

Santini, M., Grimaldi, S., Nardi, F., Petroselli, A., Rulli, M. C. 2010:

Schulz, W. H. 2007: Landslide susceptibility revealed by LIDAR imagery and historical records, Seattle, Washington. Engineering Geology 89-1,2. DOI: https://doi.org/10.1016/j.enggeo.2006.09.019

Soeters, R., van Westen, C. J. 1996: Slope instability recognition, analysis and zonation. Landslides. Investigation and Mitigation. Washington D. C.

Tarolli, P., Sofia, G., Dalla Fontana, G. 2012: Geomorphic features extraction from high resolution topography: Landslide crowns and bank erosion. Natural Hazards 61-1. DOI: https://doi.org/10.1007/ s11069-010-9695-2

Tarolli, P., Tarboton, D. G. 2006: A new method for determination of most likely landslide initiation points and the evaluation of digital terrain model scale in terrain stability mapping. Hydrology and Earth System Sciences 10. DOI: https://doi.org/10.5194/hess-10-663-2006

The international geotechnical societies' UNESCO working party for world landslide Inventory: Multilingual landslide glossary. Richmond, 1993.

UNESCO working party on world landslide inventory: A suggested method for describing the activity of a landslide. Bulletin of the International Association of Engineering Geology 47.

Urciuoli, G., Comegna, L., Di Maio, C., Picarelli, L. 2016: The Basento valley: A natural laboratory to understand the mechanics of earthflow. Rivista Italiana di Geotecnica 50-1.

Van Den Eeckhaut, M., Poesen, J., Verstraeten, G., Vanacker, V., Nyssen, J., Moeyersons, J., van Beek, L. P. H., Vandekerckhove, L. 2007: Use of LIDAR-derived images for mapping old landslides under forest. Earth Surface Processes and Landforms 32-5. DOI: https://doi.org/10.1002/esp.1417

Varnes, D. J. 1978: Slope movement types and processes. Landslides, Analysis and Control. Special Report 176. Washington, D. C.

Varnes, D. J. 1984 Landslide hazard zonation: A review of principles and practice. Natural Hazards 3. Paris.

Vukanović, M., Dimitrijević, M., Dimitrijević, M. N., Karajičić, Lj., Rakić, M. O. 1970: Tumač za Osnovnu geološku kartu 1:100,000, list Vranje. Savezni geološki zavod. Beograd. 